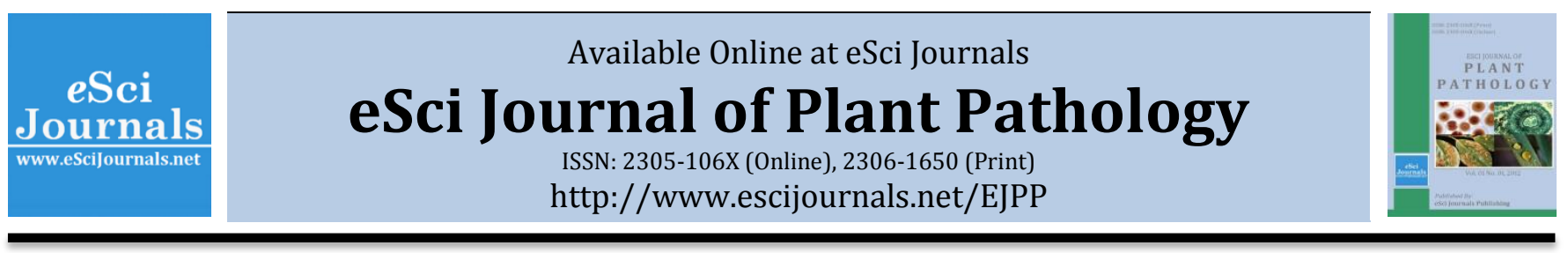

\title{
ROLE OF EPIDEMIOLOGICAL AND BIOCHEMICAL FACTORS AGAINST EARLY BLIGHT OF POTATO
}

\author{
aSaira Mehboob, bAbdul Rehman, bMuhammad A. Khan, aMuhammad Idrees \\ a Plant Pathological Research Institute, Ayyub Agricultural Research Institute Faisalabad, Pakistan. \\ b Department of Plant Pathology, University of Agriculture Faisalabad, Pakistan.
}

\begin{abstract}
A B S T R A C T
Epidemiological and biochemical factors play a significant role in early blight disease development in potatoes. For this 29 test cultivars/ lines, were screened, 15 lines including Cardinal and Desiree were found to be very highly susceptible. Eight lines including Diament FSD-White, and TPS-9813 showed highly susceptible response. Two lines i.e. 9802 and 396266-33 were susceptible. Only one variety /advanced line FD-1-8 was found to be resistant. None of the 29 advanced lines was found to be highly resistant while two lines such as FD-3-9 and FD-48-41 were shown moderately resistant response. At varietal level, among 29 test varieties/ advanced lines, all the varieties showed highly significant correlation with minimum temperature and negative correlation with maximum temperature. 18 varieties/advanced lines have significant correlation with pan evaporation. Whereas all the 29 varieties/ advanced lines did not show any correlation with relative humidity and wind speed. Five varieties/ advanced lines namely Cardinal, 396240-181, 9803, FD-1-9 and 9801 were selected to study the relationship of environmental conditions with disease severity. Maximum disease severity was recorded at $17-20^{\circ} \mathrm{C}$ maximum temperature, $6-9^{\circ} \mathrm{C}$ of minimum air temperature and 1.9-2.4 mm pan evaporation. Relative humidity and wind speed almost had no significant effect on disease severity. On varietal level early blight disease severity had significant correlation with phenolic production both in leaves and tubers. Among 29 varieties, 20 varieties had significant correlation with phenolic production while 9 had no correlation in case of leaves while in case of tubers 19 varieties/ lines showed significant correlation \& 10 lines did not show any correlation with phenolics production.
\end{abstract}

Keywords: Alternaria solani, Varietal screening, Environmental factors, Phenolic studies.

\section{INTRODUCTION}

Potato (Solanum tuberosum L.) belongs to Solanaceae family. It is world's leading vegetable crop by virtue of its inherent potential for tonnage production, remunerative income and food values. In Pakistan the crop was cultivated on large area of about 3,000 hectares in 1947-48 with an annual production of 27,000 tons (Anonymous, 1989). Whereas at present the potato occupies an area of about 115.8 thousand ha with an average yield of 24.6 thousand $\mathrm{kg} / \mathrm{ha}$. in Pakistan (Anonymous, 2010). It is ranked $4^{\text {th }}$ among the widely cultivated crops in Asia in relation to its importance and human consumption. The average yield of potato ha ${ }^{-1}$ is verv low in Pakistan as compared to

* Corresponding Author:

Email: arb041@gmail.com

(c) 2012 eSci Journals Publishing. All rights reserved. other potato growing countries. A significant part of produce is lost due to pests and diseases (Kelman, 1984).

There are several factors contributing to low potato production in Pakistan. Among these, diseases being the most important factor. In Pakistan potato is attacked by number of diseases caused by different pathogens. Early blight of potato caused by Alternaria solani (Ellis and Mar.) Jones and Grout, is an important fungal disease, which is widely distributed and damaging. This pathogen is also known to attack tomatoes, chilies and eggplant. It becomes more serious on early-planted crop and becomes a productionlimiting factor in some years (Malik and Khan, 1967). So, present studies were designed to screen germplasm and evaluate various biochemical and environmental factors contributing this disease. 


\section{MATERIAL AND METHODS}

Establishment of disease screening nursery under field conditions: A disease screening nursery comprising of 29 varieties/ advanced lines was established in the research area of Plant Pathology Department, during 2005-2006. The tubers were obtained from National Agriculture Research center, Islamabad and Ayub Agriculture Research Institute, Faisalabad. Each variety / line was sown in two rows of four meter length with $20 \mathrm{~cm}$ plant to plant and $60 \mathrm{~cm}$ row to row distance. The diseased screening nursery was watered by surface irrigation at regular intervals
(6- 8 days) throughout the season and stopped 15 days before harvesting. The incidence of disease was recorded soon after the appearance of disease and was assessed as:

$\%$ incidence of early blight $=\frac{\text { No. of infected plants }}{\text { Total number of plants }} \times 100$ The severity of the disease was also recorded on weekly bases using 0-9 scale of Reifschneider et al., (1984). Where 0 means no visual symptoms was observed and 9 mean all leaves and stems drying and dead due to disease.

Table 1. Disease estimation scale for early blight of potato

\begin{tabular}{|c|c|c|}
\hline Grade & \% age blight & Nature of Infection (level of resistance /susceptibility) \\
\hline 0 & 0.0 & No disease observed immune. \\
\hline 1 & 0.1 & A few scattered plants blighted but 1 or 2 spots / plant (very high resistant). \\
\hline 2 & 1.0 & A few scattered plants blighted but 5-10 spots / plant (Highly resistant). \\
\hline 3 & 5.0 & A few plant blighted but $11-25$ spots / plant (resistant). \\
\hline 4 & 10.0 & A few plant blighted but $26-50$ spots / plant (Moderately resistant). \\
\hline 5 & 25.0 & $\begin{array}{l}\text { Blighted plants more common nearly every leaf let infected but plant remain normal } \\
\text { in form, field looks normal green (Moderately susceptible). }\end{array}$ \\
\hline 6 & 50.0 & $\begin{array}{l}\text { Every plant affected and about } 5 \% \text { of leaf area destroyed, field appears green flecked } \\
\text { with brown (Susceptible). }\end{array}$ \\
\hline 7 & 75.0 & $\begin{array}{l}\text { About } 75 \% \text { of leaf area destroyed, field appears neither predominately brown nor } \\
\text { green (Highly susceptible). }\end{array}$ \\
\hline 8 & 95.0 & Only a few leaves on plants but stem green (Very Highly Susceptible). \\
\hline 9 & 100 & All leaves dead, stem dead or drying (Very Highly Susceptible). \\
\hline
\end{tabular}

Reifschneider et al., 1984. (Severity assessment on visual basis)

Biological activity of Alternaric acid: Richard solution was used for extraction of Alternaric acid from the pure culture of $A$. solani. Ingredients of Richard solution are:

$\begin{array}{ll}\mathrm{KNO}_{3} & =10 \mathrm{~g} \\ \mathrm{MKP} & =5 \mathrm{~g} \\ \mathrm{MgSO}_{4} .7 \mathrm{H}_{2} \mathrm{O} & =2.50 \\ \mathrm{FeCl}_{3} & =0.02 \mathrm{~g} \\ \text { Sucrose } & =50 \mathrm{~g} \\ \text { Distilled Water } & =1 \mathrm{~L}\end{array}$

All the ingredients were mixed in $1 \mathrm{~L}$ of water and poured in 4 flasks each of $250 \mathrm{ml}$. These flasks were autoclaved and inoculated with a bit ( $2 \mathrm{~mm}$ ) of 15 days old pure culture of $A$. solani. Then these flasks were incubated at $24-25^{\circ} \mathrm{C}$ for $14-15$ days. After 15 days there was sufficient growth of mycelium of Alternaria solani in culture medium. The culture was filtered and poured into small Petri plates. Healthy samples were collected from different solanaceous plants like potato, tomato, eggplant, chilies, phaseolus, petunia and tobacco. Very thin cross sections of stem of each sample were cut and dipped in each of the petri plates containing culture filtrates to observe the biological activity of Alternaric acid and cross section in sterilizes water was served as control. Tissues necrosis of cross sections of stem was observed under stereoscope after every half 4,8 and 12 hours. Frequency of tissues necrosis was recorded on different solanaceous plants and compared it with control.

\section{RESULTS AND DISCUSSION}

Screening of potato varieties/advanced lines against Alternaria solani: Out of 29 test cultivars, only one variety e was found to exhibit immunity against early blight disease under natural conditions in the field (Table 2). Absence of immunity in germplasm has been also reported by Khan et al; (2001).Early blight of potato is a wide spread disease and has been reported in all potato growing areas of the world. The pathogen often becomes destructive to the potato crop at early growth stages, depending upon suitable temperature 
and moisture conditions. In case of severe attack the entire plant becomes defoliated leading to the death and heavy yield losses by reducing the number and size of potato tubers. Singh (1994) reported that the disease becomes serious when the season begins with abundant moisture and frequent rain. Drought conditions can check the spread and disease intensity caused by $A$. solani and it is mostly correlated with previous level of intensity, plant age and average $\mathrm{RH}$ $80 \%$ at $10-20^{\circ} \mathrm{C}$. Chauhan (1985) screened 30 varieties of potato in the field by using an aqueous suspension of A. solani containing 400-500 spores / $\mathrm{ml}$.
Twenty varieties were moderately to highly susceptible and none was immune. Khan et al., (2001) screened twenty-five potato varieties/ advanced lines against early blight disease under natural and artificial inoculums. The crop was kept in good conditions through agronomic practices but no fungicide was sprayed to develop maximum disease pressure. None of the commercially grown varieties was found resistant. Two varieties showed moderately susceptible response. Sixteen were susceptible and six varieties exhibited highly susceptible response.

Table 2. Response of Potato Varieties/Advanced lines to early blight infection caused by Alternaria solani.

\begin{tabular}{|c|c|c|c|}
\hline $\begin{array}{c}\text { Name of Potato } \\
\text { varieties/advanced lines }\end{array}$ & $\begin{array}{c}\text { Disease severity rating } \\
\text { grade }\end{array}$ & $\begin{array}{c}\text { Disease severity } \\
\text { rating\% age }\end{array}$ & $\begin{array}{c}\text { Level of resistance/ } \\
\text { susceptibility }\end{array}$ \\
\hline $39403-16$ & 9 & $100 \%$ & VHS \\
\hline $394005-115$ & 9 & $100 \%$ & VHS \\
\hline Cardinal & 9 & $100 \%$ & VHS \\
\hline Desiree & 8 & $95 \%$ & VHS \\
\hline FD-3-15 & 8 & $95 \%$ & VHS \\
\hline 391202 & 8 & $95 \%$ & VHS \\
\hline 9808 & 8 & $95 \%$ & VHS \\
\hline SH-5 & 8 & $95 \%$ & VHS \\
\hline $396240-21$ & 8 & $95 \%$ & VHS \\
\hline $394028-37$ & 8 & $95 \%$ & VHS \\
\hline $394055-40$ & 8 & $95 \%$ & VHS \\
\hline FD-48-1 & 8 & $95 \%$ & VHS \\
\hline FD-49-29 & 8 & $95 \%$ & VHS \\
\hline FD-35-36 & 8 & $95 \%$ & VHS \\
\hline $393574-61$ & 8 & $95 \%$ & VHS \\
\hline 9803 & 8 & $75 \%$ & HS \\
\hline Diament & 7 & $75 \%$ & HS \\
\hline $396240-181$ & 7 & $75 \%$ & HS \\
\hline 9801 & 7 & $75 \%$ & HS \\
\hline TPS-9813 & 7 & $75 \%$ & HS \\
\hline 9814 & 7 & $75 \%$ & HS \\
\hline FSD-White & 7 & $75 \%$ & HS \\
\hline FD-1-9 & 7 & $75 \%$ & HS \\
\hline 9802 & 6 & $50 \%$ & S \\
\hline $396266-33$ & 6 & $50 \%$ & S \\
\hline $394021-120$ & 5 & $25 \%$ & MS \\
\hline FD-48-41 & 4 & $10 \%$ & MR \\
\hline FD-3-9 & 4 & $10 \%$ & MR \\
\hline FD-1-8 & 3 & $5 \%$ & $\mathrm{R}$ \\
\hline
\end{tabular}

Where; VHS = Very highly susceptible, HS = highly susceptible, $\mathrm{S}=$ Susceptible, $\mathrm{MS}=$ Moderately susceptible, $\mathrm{MR}=$ Moderately resistant, $\mathrm{R}=$ Resistant.

Singh (1994) reported that the disease becomes serious when the season begins with abundant moisture and frequent rain. Drought conditions can check the spread and disease intensity caused by A. solani and it is mostly correlated with previous level of intensity, plant age and average $\mathrm{RH} 80 \%$ at $10-20{ }^{\circ} \mathrm{C}$. Chauhan (1985) screened 30 varieties of potato in the field by using an aqueous suspension of $A$. solani containing 400-500 spores / ml. Twenty varieties were moderately to highly susceptible and none was immune. Khan et al., 
(2001) screened twenty-five potato varieties/ advanced lines against early blight disease under natural and artificial inoculums. The crop was kept in good conditions through agronomic practices but no fungicide was sprayed to develop maximum disease pressure. None of the commercially grown varieties was found resistant. Two varieties showed moderately susceptible response. Sixteen were susceptible and six varieties exhibited highly susceptible response.

Relationship of environmental conditions with early blight disease development on five varieties/ lines of potato: Five varieties/ advanced lines namely Cardinal, 396240-181, 9803, FD-1-9 and 9801 were selected to study the relationship of environmental conditions with disease severity. Temperature played a vital role in the development of disease on these varieties/ lines. Maximum disease severity was recorded at $17-20^{\circ} \mathrm{C}$ maximum temperatures and $6-9^{\circ} \mathrm{C}$ of minimum air temperature. There was overall decreasing trend of disease development at maximum air temperature i.e. $17-24{ }^{\circ} \mathrm{C}$ and log expression models indicated by very high $R_{2}$ values on all the five varieties also explained increasing trend of disease development at minimum air temperature of $3-9^{\circ} \mathrm{C}$. Highest disease severity was recorded at $1.9-2.4 \mathrm{~mm}$ pan evaporation. All the varieties/ lines showed increasing trend of disease severity from $1.4-2.4 \mathrm{~mm}$ pan evaporation. Relative humidity and wind speed almost had no significant effect on disease severity.

Table. No. 3. Disease severity assessment on different potato varieties and its correlation with environmental conditions

\begin{tabular}{|c|c|c|c|c|c|c|}
\hline $\begin{array}{l}\text { Sr. } \\
\text { No. }\end{array}$ & $\begin{array}{c}\text { Disease } \\
\text { Severity } \\
\text { (Early Blight) }\end{array}$ & $\begin{array}{c}\text { Maximum } \\
\text { Temperature } \\
\left({ }^{\circ} \mathrm{C}\right)\end{array}$ & $\begin{array}{c}\text { Minimum } \\
\text { Temperature } \\
\left({ }^{\circ} \mathrm{C}\right)\end{array}$ & $\begin{array}{c}\text { R.H } \\
\%\end{array}$ & $\begin{array}{c}\text { Pan. } \\
\text { Evaporation }\end{array}$ & $\begin{array}{l}\text { Wind Speed } \\
\mathrm{km} / \mathrm{h}\end{array}$ \\
\hline \multirow{2}{*}{1} & $39403-16$ & $0.22675^{*}$ & 0.66196 & 0.06353 & $0.54125^{*}$ & 0.12276 \\
\hline & & 0.3984 & 0.0052 & 0.8152 & 0.0304 & 0.6506 \\
\hline \multirow{2}{*}{2} & $3944005-115$ & $-0.26601^{*}$ & 0.64312 & 0.15572 & 0.39227 & 0.1046 \\
\hline & & 0.3193 & 0.0072 & 0.5647 & 0.1329 & 0.6997 \\
\hline \multirow{2}{*}{3} & Cardinal & $-0.21693^{*}$ & 0.60786 & 0.03241 & $0.53108^{*}$ & 0.10912 \\
\hline & & 0.4197 & 0.0125 & 0.9052 & 0.0343 & 0.6875 \\
\hline \multirow[b]{2}{*}{4} & Desire & -0.21566 & $0.68678^{*}$ & 0.22669 & 0.34646 & 0.04446 \\
\hline & & 0.4401 & 0.0047 & 0.4165 & 0.2058 & 0.8750 \\
\hline \multirow{2}{*}{5} & FD-3-15 & -0.21249 & $0.67726^{*}$ & 0.09648 & 0.44684 & 0.04247 \\
\hline & & 0.4295 & 0.0039 & 0.7223 & 0.0827 & 0.8759 \\
\hline \multirow{2}{*}{6} & 391202 & -0.12104 & $0.59313^{*}$ & -0.05902 & 0.56013 & 0.05809 \\
\hline & & 0.6552 & 0.0154 & 0.8281 & $0.0240^{*}$ & 0.8308 \\
\hline \multirow{2}{*}{7} & 9808 & -0.25029 & $0.62987^{*}$ & 0.07922 & 0.44446 & 0.10241 \\
\hline & & 0.3498 & 0.0089 & 0.7706 & 0.0846 & 0.7059 \\
\hline \multirow{2}{*}{8} & SH-5 & -0.18024 & $0.68413^{*}$ & 0.07067 & $0.49117^{*}$ & 0.04007 \\
\hline & & 0.5042 & 0.0035 & 0.7948 & 0.0534 & 0.8829 \\
\hline \multirow{2}{*}{9} & $396240-21$ & -0.177743 & 0.62736 & 0.03682 & $0.53814^{*}$ & 0.08574 \\
\hline & & 0.5109 & 0.0093 & 0.8923 & 0.0315 & 0.7522 \\
\hline \multirow[b]{2}{*}{10} & $394028-37$ & -0.25598 & $0.72903^{*}$ & 0.15805 & 0.46199 & 0.10954 \\
\hline & & 0.3386 & 0.0014 & 0.5588 & 0.0716 & 0.6863 \\
\hline \multirow{2}{*}{11} & $-394055-40$ & -0.15482 & $0.66796^{*}$ & 0.00789 & $0.55050^{*}$ & 0.05490 \\
\hline & & 0.5670 & 0.0047 & 0.9769 & 0.0271 & 0.8400 \\
\hline \multirow{2}{*}{12} & FD-48-1 & -0.21817 & $0.63961^{*}$ & 0.07422 & $0.49431^{*}$ & 0.10412 \\
\hline & & 0.4169 & 0.0076 & 0.7847 & 0.0516 & 0.7012 \\
\hline \multirow{2}{*}{13} & FD-35-36 & -0.14363 & $0.66237^{*}$ & -0.00906 & $0.58541^{*}$ & 0.07145 \\
\hline & & 0.5956 & 0.0052 & 0.9734 & 0.0172 & 0.7926 \\
\hline \multirow{2}{*}{14} & FD-49-29 & -0.22453 & $0.61601^{*}$ & 0.04413 & $0.51589 *$ & 0.11847 \\
\hline & & 0.4031 & 0.0111 & 0.8711 & 0.0408 & 0.6621 \\
\hline \multirow{2}{*}{15} & $393574-61$ & -0.33218 & $0.62951^{*}$ & 0.13152 & 0.39448 & 0.16187 \\
\hline & & 0.2088 & 0.0090 & 0.6273 & 0.1305 & 0.5492 \\
\hline \multirow{2}{*}{16} & 9803 & -0.26361 & 0.58274 & 0.03977 & 0.50260 & 0.13867 \\
\hline & & 0.3239 & 0.0178 & 0.8837 & 0.0472 & 0.6085 \\
\hline
\end{tabular}




\begin{tabular}{cllllll}
\hline $\begin{array}{c}\text { Sr. } \\
\text { No. }\end{array}$ & $\begin{array}{c}\text { Disease } \\
\text { Severity } \\
(\text { Early Blight })\end{array}$ & $\begin{array}{c}\text { Maximum } \\
\text { Temperature } \\
\left({ }^{\circ} \mathrm{C}\right)\end{array}$ & $\begin{array}{c}\text { Minimum } \\
\text { Temperature } \\
\left({ }^{\circ} \mathrm{C}\right)\end{array}$ & $\begin{array}{c}\text { R.H } \\
\%\end{array}$ & $\begin{array}{c}\text { Pan. } \\
\text { Evaporation }\end{array}$ & $\begin{array}{c}\text { Wind Speed } \\
\mathrm{km} / \mathrm{h}\end{array}$ \\
\hline \multirow{2}{*}{17} & Diament & -0.22872 & 0.66290 & 0.11996 & 0.43879 & 0.06991 \\
& & 0.3942 & 0.0051 & 0.6581 & 0.0891 & 0.7970 \\
18 & \multirow{2}{*}{$396240-181$} & -0.17891 & $0.68178^{*}$ & 0.03965 & $0.51777^{*}$ & 0.07978 \\
& & 0.5074 & 0.0036 & 0.8841 & 0.0399 & 0.7690 \\
19 & 9801 & -0.17265 & $0.68086^{*}$ & 0.03129 & $0.50707^{*}$ & 0.05674 \\
& & 0.5226 & 0.0037 & 0.9084 & 0.0450 & 0.8347 \\
20 & TPS-9813 & -0.17298 & $0.67365^{*}$ & 0.03905 & $0.48544^{*}$ & 0.3296 \\
& & 0.5218 & 0.0042 & 0.8858 & 0.0566 & 0.9035 \\
21 & 9814 & -0.15980 & $0.58825^{*}$ & -0.0257 & $0.57818^{*}$ & 0.07973 \\
& & 0.5544 & 0.0165 & 0.9245 & 0.0190 & 0.7691 \\
22 & FSD-White & -0.23707 & $0.61237^{*}$ & 0.9604 & 0.45356 & 0.006890 \\
& & 0.3769 & 0.0117 & 0.7235 & 0.0776 & 0.7999 \\
23 & FD-1-9 & -0.17274 & $0.66055^{*}$ & 0.04000 & $0.50094^{*}$ & 0.02852 \\
& & 0.5223 & 0.0053 & 0.8831 & 0.0481 & 0.9165 \\
24 & 9802 & -0.19416 & 0.63834 & 0.06789 & 0.46190 & 0.06122 \\
& & 0.4712 & 0.0078 & 0.8027 & 0.0717 & 0.8218 \\
25 & $396266-33$ & -0.27034 & $0.67893^{*}$ & 0.20298 & 0.39519 & 0.06376 \\
& & 0.3112 & 0.0038 & 0.4509 & 0.1298 & 0.8145 \\
26 & \multirow{2}{*}{$394021-120$} & -0.06902 & $0.57804^{*}$ & -0.0623 & $0.54786^{*}$ & -0.04005 \\
& & 0.7995 & 0.0190 & 0.8187 & 0.0280 & 0.8829 \\
27 & FD-48-41 & -0.04562 & 0.49146 & -0.16878 & $0.51886^{*}$ & -0.05395 \\
& & 0.8668 & 0.0532 & 0.5321 & 0.0395 & 0.8427 \\
28 & FD-3-9 & -0.02213 & $0.6326^{*}$ & -0.1246 & 0.68506 & -0.07292 \\
& & 0.9352 & 0.0085 & 0.6456 & 0.0034 & 0.7884 \\
29 & FD-1-8 & -0.30934 & $0.61037^{*}$ & 0.09202 & 0.32626 & 0.14030 \\
& & 0.2437 & 0.0120 & 0.7346 & 0.2175 & 0.6043 \\
\hline
\end{tabular}

Upper values indicate Pearson's correlation coefficients, Lower values in a column indicate level of probability

*= Significant at $\mathrm{P}=0.05$

Effect of Alternaric acid produced by Alternaria solani on tissue necrosis of Solanaceous plants: Alternaric acid extracted from pure culture of Alternaria solani in Richard solution was used to study its biological activity. Very thin cross sections of different solanaceous plants were cut and dipped in culture filtrates and observed for tissue necrosis under stereoscope. The observations were made after 4 hours, 8 hours and 12 hours (Table 4).

After $4^{\text {th }}$ hour no necrosis was observed in potato, eggplant and tobacco tissues and $25 \%$ necrosis was observed in tomato, chilies, phaseolus and petunia tissues. After $8^{\text {th }}$ hour, $50 \%$ necrosis was observed in phaseolus and petunia followed by potato, tomato, eggplant, and chilies in which $25 \%$ tissue necrosis was observed, whereas no tissue necrosis was observed in case of tobacco.

After 12 hours, $75 \%$ necrosis was observed in phaseolus and petunia followed by $50 \%$ tissues necrosis in potato, tomato, eggplant and chilies whereas only $25 \%$ tissue necrosis was observed in case of tobacco.
Table 4: Effect of Alternaric acid on tissue necrosis in Solanaceous Plants

\begin{tabular}{lccc}
\hline & 4 hours & 8 hours & 12 hours \\
\hline Potato & 0 & 25 & 50 \\
Tomato & 25 & 25 & 50 \\
Egg plant & 0 & 25 & 50 \\
Chillies & 25 & 25 & 50 \\
Phaseolus & 25 & 50 & 75 \\
Petunia & 25 & 50 & 75 \\
Tobaccoo & 0 & 0 & 25 \\
\hline
\end{tabular}

Brain et al., (1949) described the phytotoxic property of alternaric acid produced by $A$. solani, which caused wilting and collapse of plant tissues in advance of the infection. The concentration of $5-10 \mu \mathrm{gm} / \mathrm{ml}$ of alternaric acid caused severe wilting of radish, cabbage, mustard and carrot seedlings after an interval of 7-10 days. Seeds of radish, mustard, tomato, clover and wheat were incubated on agar containing alternaric acid. The growth of radish mustard and tomato was severely retarded by $1-5 \mu \mathrm{gm} / \mathrm{ml}$ of alternaric acid but wheat and clover were somewhat resistant. 
Brian et al., again in 1951 studied and extracted the biologically active metabolic product of $A$. solani i.e. alternaric acid, its production and antifungal properties and reported that the quantity of alternaric acid produced was directly related to the amount of mycelium formed. Optimal media for growth of mycelium contained high concentration of sucrose. Alternaric acid was not antibacterial however germination of spores of some fungi was prevented by alternaric acid. During another study Wheeler and Luke (1963) isolated the alternaric acid from the culture filtrates of $A$. solani and observed that $5-10 \mu \mathrm{gm} / \mathrm{ml}$ of alternaric acid in nutrient solution caused severe wilting of a number of plants not parasitized by $A$. solani. During inoculation of studies, tomato fruits with a number of isolates, which varied in pathogenicity, they found that least virulent strain produced the highest toxin and the most pathogenic strain apparently produced no toxin. So, it was suggested that there was no correlation between alternaric acid production and pathogenicity. During screening of cultivar Brune et al., (1997) tested 184 Solanum tuberosum clones, obtained from 47 crosses. Clones identified as resistant were evaluated for several agronomic and quality characters such as dry matter and chip quality. Nine clones were found resistant against early blight of potato. Funk and Gilbert (2003) descried that susceptibility of tomato and potato to $A$. solani infection was primarily affected by the age of host plant. Infection was accompanied by the production of toxins by $A$. solani, including some nonhost specific toxins called alternatic acid, altersolanol and macrosporin. These toxins caused the disease in host plant by acting on the plant protoplast to disturb physiological processes that sustained plant health. $A$. solani caused collar rot in tomato seedlings and early blight in mature tomato and potato.

\section{REFERENCES}

Anonymous, 2010. Agriculture Statistics of Pakistan. Govt. of Pakistan, Ministry of Food, Agriculture and Livestock Div. Islamabad. pp.436

Anonymous, 1989. Potato atlas of Pakistan. Information on potato production by Agro ecological Zones. PSDP, ARC, Islamabad.
Bambawale, Q.M. 1988. A model for predicting severity on early blight of potato in the Punjab. Plant Disease Research. 3(1): 11-16

Brian, P.W., P.J. Curtis, H.G. Hemming, C.H. Unwin and J. M. Wright. 1949. Alternaric acid, a biologically active metabolic product of the fungus Alternaria solani. Nature. 164: 534.

Brain, P.W., P.J. Curtis, H.G. Hemming, E.G. Jefferys, C.H. Unwin and J.M. Wright. 1951. A biologically active metabolic product of Alternaria solani (Ell \& Mart). Jones and Grout; its production, isolation and antifungal properties. J. Gen. Microbiol. 5: 619-632.

Brune, S., P.E. Melo and M.F. Lima. 1997. Resistance to Alternaria solani, marketable characteristics and frying quality of potato clones showing inanity to PVY and PVX. Horticulture. Brasileira. 12 (2): 125-130.

Chauhan, M.S. 1985. Reaction of potato varieties and hybrids to early blight disease. Haryana Agri. Univ. J. Res. 15(4): 465-466

Funk, L and G. Gilbert. 2003. Compendium of plant pathogens and diseases. Center for Agro etiology and Sustainable Food System (CASFS). University of California, Santa Cruz. USA. pp707

Kelman, A.H.E. 1984. Post-harvest pathology of fruits and vegetables. Univ. Calif. Agri. Exp. Stn. Bull. 1914: 1-3.

Khan M.A., A. Hafeez and K. Farooq. 2001. Screening of potato varieties / lines against early blight disease caused by $A$. solani (Ellis and Mart) Jones \& Grout. Pak. J. Phytopathol. 13 (2): 124-126.

Malik, S.A. and M.A. Khan, 1967. Investigations on the control of early blight of potato caused by Alternaria solani (Ellis and Mart) Jones and Grout. W. Pak. J. Agric. Res. 5:92-97.

Reifschneider, F.J.B., P. Furumoto and F.A.R. Rilgueira. 1984. Illustrated key for the evaluation of early blight of potato. FAO. PI. Prot. Bull. 32(3): 91-94

Singh, R.S. 1994. Plant Diseases. 6th Edition. Oxford and IBH Publishing Co. (Pvt.) Ltd., New Delhi, India.

Wheeler, H. and H.H. Luke. 1963. Microbiol toxins in plant disease. Ann. Rev. Microbiol. 17: 223-242. 